\title{
Primjena strategija aktivnoga učenja i poučavanja u nastavi prirode i društva
}

\author{
Ana-Marija Bahat ${ }^{1}$, Žaklin Lukša ${ }^{2}$ \\ 1 Učiteljski fakultet Zagreb, Odsjek u Čakovcu, Dr. Ante Starčevića 55, 40000 Čakovec \\ ${ }^{2}$ Gimnazija Josipa Slavenskog Čakovec, V. Nazora 34, 40000 Čakovec
}

zaklin.luksa@skole.hr

\begin{abstract}
SAŽETAK
Aktivno učenje i korištenje strategija, metoda i postupaka koji ga potiču, temelj su suvremene nastave. Prema prijedlogu Nacionalnog kurikuluma nastavnoga predmeta Priroda i društvo (2016), znanja, vještine i stavovi stečeni u ovome predmetu trebali bi učeniku omogućiti razumijevanje i snalaženje u svijetu oko sebe. To se može postići aktivnim učenjem i poučavanjem, u učionici ili izvan nje. U našem školskom sustavu, unatoč brojnim činjenicama koje upućuju na prednosti aktivnoga učenja i poučavanja, još uvijek prevladava tradicionalna nastava. Ciljevi ovog rada i istraživanja bili su procijeniti u kojoj mjeri učitelji razredne nastave primjenjuju strategije aktivnoga učenja i poučavanja u nastavi Prirode i društva te slažu li se percepcija studenata i tvrdnje učitelja o tome koliko učitelji koriste aktivne oblike učenja i poučavanja. U istraživanju je sudjelovalo 116 učitelja razredne nastave iz dvanaest škola s područja Varaždinske, Krapinsko-zagorske i Koprivničko-križevačke županije i 106 budućih učitelja. Rezultati su pokazali da je najčešće korištena strategija direktnog poučavanja, a najrjeđe strategija aktivnoga učenja uz primjenu suvremene informacijsko-komunikacijske tehnologije. Studenti procjenjuju učestalost korištenja svih strategija aktivnoga učenja i poučavanja rjeđom nego što to procjenjuju sami učitelji. Dobiveni rezultati ukazuju na potrebu promjene odgojno-obrazovnog sustava, koja treba biti usmjerena k većoj uključenosti aktivnih oblika učenja i poučavanja u nastavi.
\end{abstract}

Ključne riječi: strategije aktivnoga učenja i poučavanja; Priroda i društvo; nastava usmjerena na učenika; razredna nastava

\section{UVOD}

Tradicionalna (predavačka, frontalna) nastava je usmjerena na učitelja, na nastavni sadržaj te plan i program, a suvremena je nastava usmjerena na učenika, u kojoj učitelj ima ulogu organizatora, mentora i ravnopravnog suradnika s učiteljima, roditeljima i drugim suradnicima (Stevanović, 2004). Našem školskom sustavu potrebne su promjene, potrebno se okrenuti suvremenoj nastavi $i$ mogućnostima koje nam ona nudi - usmjeriti se na stvaranje kvalitetne škole. Kvalitetna škola je škola koja učenika stavlja u nastavni proces kao aktivnog sudionika, škola koja zadovoljava potrebe učenika i u kojoj učitelji teže boljem u suradnji sa svojim učenicima (Glasser, 1994). Većina učitelja svjesna je potrebe za promjenama, ali postoje mnogi čimbenici koji utječu na rad i odluke učitelja (Kovačević, 2005). Učitelji ne mogu sami promijeniti školski sustav - potrebno je pokrenuti i nadležne institucije, koje bi učiteljima omogućile kvalitetno stručno i cjeloživotno usavršavanje usmjereno na cjeloviti razvoj učenika, koje bi trebalo osposobiti primijeniti naučeno u životu (Stevanović, 2004). Cjeloživotno stručno usavršavanje učitelja smatra se imperativom toga zvanja te je to najvažniji preduvjet za uspješnu provedbu promjena i napredovanja školskog sustava (Matijević i Radovanović, 2011). Najveći doprinos učenju učenika, njihovom napretku, razvoju i uspješnosti, je učenje samih učitelja te zbog toga suvremena škola mora biti u kontinuiranom razvoju i mijenjaju, kao i učitelji koji je svojim radom mijenjaju (Stoll i Fink, 2000).

Prema prijedlogu Nacionalnog kurikuluma nastavnoga predmeta Priroda i društvo (2016), znanja, vještine i stavovi stečeni u ovome predmetu trebali bi učeniku omogućiti razumijevanje svijeta u kojemu se nalazi te lakše snalaženje $u$ istome. To se može postići aktivnim učenjem i poučavanjem, $u$ učionici ili izvan nje. Isto se može pronaći i u Nacionalnom okvirnom kurikulumu (2011), kao i u Nastavnom planu i programu (2006).

Bahat, A.M., Lukša, Ž. (2019). Primjena strategija aktivnoga učenja i poučavanja u nastavi prirode i društva. Educ. biol., 5:17-29. URL DOI: https://doi.org/10.32633/eb.5.2 
Postoji mnogo definicija aktivnoga učenja, ali i sinonima za isto. Mnoštvo autora umjesto ovog pojma koristi pojmove poput suvremena nastava, aktivna nastava, nastava usmjerena na učenika, poučavanje usmjereno na proces ili poučavanje usmjereno na dijete (Boras, 2009; Nikčević-Milković, 2004; Matijević i Radovanović, 2011; Džaferagić-Franca i Omerović, 2012). Iz svih se definicija može uočiti nekoliko važnih obilježja aktivnoga učenja, a to su naglasak na nastavu usmjerenu na učenika, učenje koje proizlazi iz djelovanja samoga učenika u suradnji s učiteljem te učenje čiji je krajnji rezultat cjeloviti i potpuni razvoj učenika.

Nastava usmjerena na učenika, koji je aktivni sudionik procesa, potreba je dinamične i kompleksne današnjice. Sadržaji učenja predstavljaju samo okvir, a sliku (učenik s onime što je naučio) treba tek naslikati. Hoće li slika biti kvalitetna ovisi o umjetniku (učitelju) i odabranim tehnikama (strategijama, metodama i postupcima). Odabrane strategije, metode i postupci moraju učeniku omogućiti primjenjivanje naučenoga, a primjenjivo i trajno znanje učenici mogu steći samo naporom vlastita uma (Kovačević, 2005).

Učenje i poučavanje bi trebalo biti organizirano kao proces smislenih aktivnosti tijekom kojih učenici stječu nova znanja, uzimajući u obzir prethodna iskustva učenika te bi odabrane strategije, metode i postupci trebali omogućavati učenicima propitivanje, istraživanje, refleksiju i praktične aktivnosti, uz izbjegavanje zapamćivanja činjenica (Topolovčan i sur, 2017). Aktivno učenje može biti i individualno i suradničko, a strategije koje učenika aktivno uključuju u nastavni proces i koje rezultiraju aktivnim učenjem su:

1) projektno učenje,

2) iskustveno učenje,

3) učenje rješavanjem problema,

4) učenje usmjereno na djelovanje,

5) učenje istraživanjem i otkrivanjem,

6) učenje igranjem (Topolovčan i sur, 2017; Letina 2016; De Zan, 2005; Matijević i Radovanović, 2011).

Aktivno učenje i poučavanje implementirano u nastavni predmet Prirode i društva nudi mnogobrojne mogućnosti. Strategije aktivnoga učenja i poučavanja mogu se i poželjno ih je koristiti u svim nastavnim predmetima, a posebice u predmetu Priroda i društvo koji polazi od same prirode i djetetove okoline. Spomenute strategije ne nude više mogućosti u predmetu Priroda i društvo u odnosu na ostale predmete

Obzirom na to da nastava Prirode i društva nudi učenicima velike mogućnosti da sami neposredno promatraju, opisuju, prate i dolaze do zaključaka o pojavama u svojoj okolini, potrebno je da se takva nastava organizira kao istraživački usmjerena nastava, temeljena na učeničkom iskustvu i rješavanju zadanih problema. Takva, suvremena nastava Prirodoslovlja, zahtijeva da učenici, već u nižim razredima osnovne škole, spoznaju prirodoznanstvenu metodu i prirodoslovne postupke te načine istraživanja i dolaženja do znanstvenih spoznaja, a sve s ciljem da se osposobe za samostalno spoznavanje prirode i svog okoliša (De Zan, 2005).

Provedena su mnogobrojna istraživanja o učincima aktivnoga učenja i poučavanja na učenički uspjeh i napredak (Kovačević, 2005; Seifert i sur, 2009; Schallies i Lembens, 2002; Balažinec, 2012; Harle, 2001; Calkin i sur, 2003). Rezultati ovih istraživanja pokazali su da se uključivanjem učenika u nastavni proces kao aktivnih sudionika odgovornih za svoje učenje, postižu više razine znanja, dublje razumijevanje nastavnog sadržaja, veće zadovoljstvo učenika, a samim time i veća kvaliteta nastavnog procesa. 
Međutim, u našem školskom sustavu još uvijek prevladava tradicionalna nastava, dok se aktivno učenje i poučavanje koristi samo povremeno (Letina, 2013, 2016).

Cilj ovog istraživanja bio je ispitati u kojoj mjeri učitelji razredne nastave primjenjuju strategije aktivnoga učenja i poučavanja u nastavi Prirode i društva te ispitati odnos između tvrdnji učitelja o vlastitoj primjeni strategija aktivnoga učenja i poučavanja i percepcije studenata o tome.

Iz općeg cilja istraživanja formulirana su sljedeća pitanja:

$\checkmark$ Koliko često učitelji primjenjuju aktivne oblike učenja i poučavanja i direktno poučavanje u nastavi Prirode i društva?

Koje oblike aktivnoga učenja i poučavanja u nastavi Prirode i društva učitelji primjenjuju najčešće, a koje najrjeđe?

Postoji li značajna razlika u učestalosti primjene određenih oblika učenja i poučavanja u nastavi Prirode i društva kod učitelja?

Postoji li značajna razlika u učestalosti primjene različitih oblika učenja i poučavanja u nastavi Prirode i društva između učitelja s obzirom na sljedeća obilježja: a) stručnu spremu, b) radni staž, c) sudjelovanje na stručnim skupovima, d) razred u kojem rade, e) izraženo zadovoljstvo poslom i f) sredinu u kojoj se nalazi škola u kojoj rade?

Postoji li značajna razlika između percepcije studenata o tome koliko često učitelji koriste aktivne oblike učenja i poučavanja ili direktno poučavanje i tvrdnji učitelja o korištenju strategija aktivnoga učenja i poučavanja i direktnog poučavanja?

S obzirom na navedene probleme, postavljene su sljedeće hipoteze:

F Učitelji u nastavi Prirode i društva direktno poučavanje koriste često ( $1 x$ tjedno), dok se aktivni oblici učenja i poučavanja koriste samo povremeno (1x mjesečno).

- Učitelji od navedenih aktivnih oblika učenja i poučavanja u nastavi Prirode i društva najčešće primjenjuju suradničko učenje, a najrjeđe strategije aktivnoga učenja uz primjenu informacijsko-komunikacijske tehnologije.

F Aktivne strategije učenja i poučavanja u nastavi Prirode i društva manja su zastupljene u odnosu na direktno poučavanje.

- Aktivne strategije učenja i poučavanja u nastavi Prirode i društva više su zastupljene u odnosu na direktno poučavanje u nastavi Prirode i društva ako učitelji: a) imaju višu stručnu spremu, b) imaju dulji radni staž, c) više sudjeluju na stručnim skupovima, d) rade u višim razredima, e) više izražavaju zadovoljstvo poslom i f) rade u većim (gradskim) sredinama.

Procjene studenata o učestalosti korištenja strategija aktivnoga učenja i poučavanja i direktnog poučavanja u nastavi Prirode i društva niže su od samoprocjena učitelja.

\section{METODE}

Istraživanje je provedeno u razdoblju od 20. veljače do 22. travnja 2018. godine, u dvanaest škola s područja Varaždinske, Krapinsko-zagorske i Koprivničko-križevačke županije te na Učiteljskom fakultetu Sveučilišta u Zagrebu (Čakovec i Zagreb).

U istraživanju su sudjelovala 222 ispitanika. Od toga je 116 učitelja razredne nastave i 106 budućih učitelja, studenata Učiteljskog fakulteta Sveučilišta u Zagrebu (Čakovec i Zagreb). Ispitani su učitelji s područja Varaždinske, Krapinsko-zagorske i Koprivničko-križevačke županije. Osam škola smješteno je u manjim sredinama (općina), a to su: Osnovna škola "Vinica“ (broj učitelja uključenih u istraživanje

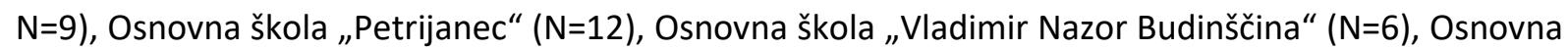
škola „Metel Ožegović Radovan“ ( $N=9$ ), Osnovna škola "Gustav Krklec Maruševec" ( $N=9)$, Osnovna škola "Cestica“ ( $N=12)$, Osnovna škola „Zlatar Bistrica“ $(\mathrm{N}=7)$, Osnovna škola „prof. Franje Viktora Šignjara Virje" ( $N=8)$. Četiri škole smještene su u gradskoj sredini i to su: I. osnovna škola Varaždin 
( $N=10)$, III. osnovna škola Varaždin ( $N=9)$, Osnovna škola "grofa Janka Draškovića Klenovnik" $(\mathrm{N}=4)$ i Osnovna škola „Ivana Kukuljevića Sakcinskog Ivanec“ (N=21).

Od ukupnog broja ispitanika $94 \%$ čine učiteljice, a $6 \%$ učitelji. Što se tiče stručne spreme, $62,1 \%$ je učitelja s višom stručnom spremom (VŠS), 35,3\% s visokom stručnom spremom (VSS). Prema radnome stažu, ispitani su učitelji podijeljeni u 6 kategorija: više od 25 godina radnoga staža $(52,6 \%)$, od 21 do 25 godina radnoga staža (15,5\%), od 16 do 20 godina radnoga staža $(7,8 \%)$, od 11 do 15 godina radnoga staža $(6,9 \%)$, od 6 do 10 godina radnoga staža $(5,2 \%)$ i od 0 do 5 godina radnoga staža $(12,1 \%)$. Nadalje, 62,1\% učitelja radi u školi koja je smještena na selu, a 37,9\% ispitanih učitelja radi u školi koja je smještena u gradu. $U$ posljednjih 5 godina $75,9 \%$ učitelja se stručno usavršavalo u temi nastavnih strategija. Od ispitanih učitelja, 29,3\% radi u drugim razredima, 26,7\% u trećim, 22,4\% u prvim, a 21,6\% u četvrtim razredima. S obzirom na zadovoljstvo poslom, ispitanici su podijeljeni u 3 kategorije: potpuno zadovoljni poslom (59,5\%), djelomično zadovoljni poslom (37,1\%) i nezadovoljni poslom $(3,4 \%)$.

Nadalje, od ispitanih studenata 87 ih polazi Učiteljski fakultet Sveučilišta u Zagrebu - odsjek u Čakovcu, dok ostalih 19 polazi Učiteljski fakultet Sveučilišta u Zagrebu. $U$ istraživanju su sudjelovala 44 studenta 4. godine $(41,5 \%)$ i 62 studenta 5. godine $(58,5 \%)$ Učiteljskog fakulteta Sveučilišta u Zagrebu (Čakovec i Zagreb). Od ispitanih studenata, 103 su studentice ( $97,2 \%)$ i samo 3 studenta (2,8\%).

Za potrebe ovog istraživanja korištena su dva anketna upitnika, jedan za učitelje razredne nastave, a drugi za buduće učitelje, studente Učiteljskog fakulteta Sveučilišta u Zagrebu (Čakovec i Zagreb). Upitnici su napravljeni po uzoru na sličan upitnik (Letina, 2016), a koji je preuzet od Hassa (2002). Upitnici su se koristili uz dozvolu vlasnice upitnika.

Anketni upitnik za učitelje sastoji se od dva dijela. Prvim su dijelom upitnika prikupljena sociodemografska obilježja ispitanika (spol, stručna sprema, staž, mjesto rada: selo/grad, razredi u kojima učitelji održavaju nastavu) te je utvrđena njihova procjena zadovoljstva poslom i sudjelovanje na stručnim skupovima. Drugim se dijelom upitnika utvrđivala učestalost primjene različitih oblika aktivnoga učenja i poučavanja te direktnog poučavanja. Taj je dio upitnika podijeljen na šest subskala koje su obuhvaćale opise različitih oblika aktivnoga učenja koje Letina (2006) ističe kao strategije koje sadrže obilježja aktivnoga učenja i poučavanja te opise tradicionalnog, direktnog poučavanja: problemsko učenje (10 pitanja), istraživačko učenje (10 pitanja), suradničko učenje (10 pitanja), aktivnosti usmjerene na razvoj komunikacijskih kompetencija učenika i njihove kompetencije učenja (15 pitanja), aktivno učenje uz primjenu suvremene informacijsko-komunikacijske tehnologije (10 pitanja) i direktno poučavanje (15 pitanja).

Anketni upitnik za studente sastojao se također od dva dijela. Prvim su dijelom prikupljena sociodemografska obilježja ispitanika (spol, godina studija) te je utvrđeno jesu li ispitani studenti održavali nastavni sat iz predmeta Priroda i društvo. Drugi dio upitnika formiran je kao i kod upitnika za učitelje, a razlika je u tome što se u ovome dijelu upitnika studente pitalo koliko često su vidjeli da učitelji koriste opisane oblike aktivnoga učenja i poučavanja i direktnog poučavanja u vrijeme kada su bili na njihovoj nastavi.

Ispitanici su učestalost primjene različitih oblika učenja u nastavi Prirode i društva trebali procijeniti na skali Likertova tipa koja se sastojala od pet stupnjeva ( $1=$ gotovo nikada, $2=$ rijetko, $3=$ povremeno, $4=$ često, $5=$ gotovo uvijek). 
Podaci su obrađeni pomoću softverskog programa za statističku obradu podataka SPSS-a. Odgovori na prve dvije hipoteze te na zadnju hipotezu analizirani su postupcima deskriptivne statistike (frekvencije, aritmetičke sredine, standardne devijacije). Postojanje razlika u korištenju različitih strategija učenja i poučavanja analizirano je primjenom ANOVE, dok je postojanje razlika u učestalosti primjene određenih oblika učenja $s$ obzirom na različite sociodemografske varijable ispitano t- testom za nezavisne uzorke za varijable $s$ dvije razine, odnosno ANOVA-om za varijable $s$ više od dvije razine. Pretpostavka o postojanju razlike između direktnog i aktivnog oblika poučavanja kod učitelja analizirana je t- testom za zavisne uzorke, dok su se razlike u tvrdnjama učitelja i percepciji studenata testirale primjenom t- testa za nezavisne uzorke.

\section{REZULTATI}

Rezultati su predstavljeni uz analizu odgovora ispitanika na anketna pitanja pri čemu sz zasebno analizirani odgovori na pitanja otvorenog tipa.

\section{Rezultati anketnoga upitnika za učitelje}

Prema samoprocjeni u anketnim upitnicima učitelji od svih strategija učenja i poučavanja najčešće primjenjuju direktno poučavanje $(M=3,93 ; S D=0,414)$ i to čine jednom tjedno (često). Od oblika aktivnoga učenja i poučavanja najčešće se primjenjuje suradničko učenje $(M=3,70$; $S D=0,488)$, a najrjeđe učenje uz primjenu suvremene informacijsko-komunikacijske tehnologije ( $M=2,90 ; S D=$ $0,631)$. Problemsko učenje $(M=3,50 ; S D=0,45)$ i aktivnosti usmjerene na razvoj komunikacijskih kompetencija učenika i njihove kompetencije učenja ( $M=3,50$; $S D=0,456)$ primjenjuju se jednom tjedno $k$ izrazitoj tendenciji prema povremenoj ( $1 x$ mjesečno) učestalosti primjene. Učitelji navode kako povremeno provode istraživačko učenje u svojim razredima $(M=3,14 ; S D=0,551)$. Samoprocjena učestalosti primjene pojedinih oblika učenja prikazana je u tablici 1. Najčešće korištena strategija je direktno poučavanje, a najrjeđe korištena je strategija aktivnoga učenja uz primjenu informacijskokomunikacijske tehnologije.

Tablica 1 Samoprocjena učitelja o učestalost primjene pojedinih strategija učenja i poučavanja (N=116)

\begin{tabular}{|c|c|c|c|c|c|}
\hline Vrsta poučavanja & $\mathbf{N}$ & $\mathbf{M i n}$ & $\mathbf{M a x}$ & $\mathbf{M}$ & SD \\
\hline Problemsko učenje & 116 & 1 & 5 & 3,50 & 0,450 \\
\hline Istraživačko učenje & 116 & 1 & 5 & 3,14 & 0,551 \\
\hline Suradničko učenje & 116 & 1 & 5 & 3,70 & 0,488 \\
\hline $\begin{array}{c}\text { Aktivnosti usmjerene na razvoj komunikacijskih } \\
\text { kompetencija učenika i njihove kompetencije učenja }\end{array}$ & 116 & 1 & 5 & 3,50 & 0,456 \\
\hline $\begin{array}{c}\text { Aktivno učenje uz primjenu suvremene informacijsko- } \\
\text { komunikacijske tehnologije }\end{array}$ & 116 & 1 & 5 & 2,90 & 0,631 \\
\hline Direktno poučavanje & 116 & 1 & 5 & 3,93 & 0,414 \\
\hline Ukupno za aktivno učenje & $\mathbf{1 1 6}$ & $\mathbf{1}$ & $\mathbf{5}$ & $\mathbf{3 , 3 6}$ & $\mathbf{0 , 3 7 4}$ \\
\hline
\end{tabular}

T-test za zavisne uzorke pokazao je da postoji statistički značajna razlika između primjene direktnog poučavanja i aktivnih strategija učenja i poučavanja $(t=69,689 ; p<0,01)$. Učitelji češće koriste direktno poučavanje $(M=3,93 ; S D=0,414)$ nego aktivne oblike učenja i poučavanja $(M=3,36 ; S D=0,374)$. Analiza rezultata također pokazuje da učitelji smatraju kako aktivne oblike primjenjuju povremeno (1x mjesečno), dok direktno poučavanje koriste često ( $1 x$ tjedno).

Rezultati pokazuju da ne postoji statistički značajna razlika ovisno o stupnju obrazovanja učitelja ni za jednu subskalu strategija učenja i poučavanja (tablica 2). 
Tablica 2 Usporedba učestalosti primjene različitih strategija učenja i poučavanja s obzirom na stručnu spremu sudionika ( $\mathrm{N}=$ 116)

\begin{tabular}{|c|c|c|c|c|c|c|c|}
\hline Vrste poučavanja & $\begin{array}{l}\text { Stručna } \\
\text { sprema }\end{array}$ & $\mathbf{N}$ & M & SD & t-test & df & $\mathbf{p}$ \\
\hline Problemsko učenje & $\begin{array}{l}\text { VŠS } \\
\text { VSS }\end{array}$ & $\begin{array}{l}72 \\
44\end{array}$ & $\begin{array}{l}3,50 \\
3,48\end{array}$ & $\begin{array}{l}0,484 \\
0,394\end{array}$ & 0,232 & 114 & 0,817 \\
\hline Istraživačko učenje & $\begin{array}{l}\text { VŠS } \\
\text { VSS }\end{array}$ & $\begin{array}{l}72 \\
44\end{array}$ & $\begin{array}{l}3,14 \\
3,15\end{array}$ & $\begin{array}{l}0,580 \\
0,506\end{array}$ & $-0,10$ & 114 & 0,992 \\
\hline Suradničko učenje & $\begin{array}{l}\text { VŠS } \\
\text { VSS }\end{array}$ & $\begin{array}{l}72 \\
44 \\
\end{array}$ & $\begin{array}{l}3,73 \\
3,65\end{array}$ & $\begin{array}{l}0,505 \\
0,461\end{array}$ & 0,812 & 114 & 0,418 \\
\hline $\begin{array}{c}\text { Aktivnosti usmjerene na razvoj } \\
\text { komunikacijskih kompetencija učenika i } \\
\text { njihove kompetencije učenja }\end{array}$ & $\begin{array}{l}\text { VŠS } \\
\text { VSS }\end{array}$ & $\begin{array}{l}72 \\
44\end{array}$ & $\begin{array}{l}3,48 \\
3,53\end{array}$ & $\begin{array}{l}0,504 \\
0,369\end{array}$ & $-0,596$ & 114 & 0,553 \\
\hline $\begin{array}{l}\text { Aktivno učenje uz primjenu suvremene } \\
\text { informacijsko-komunikacijske tehnologije }\end{array}$ & $\begin{array}{l}\text { VŠS } \\
\text { VSS }\end{array}$ & $\begin{array}{l}72 \\
44 \\
\end{array}$ & $\begin{array}{l}2,89 \\
2,92\end{array}$ & $\begin{array}{l}0,360 \\
0,508\end{array}$ & $-0,219$ & 114 & 0,827 \\
\hline Direktno poučavanje & $\begin{array}{l}\text { VŠS } \\
\text { VSS }\end{array}$ & $\begin{array}{l}72 \\
44\end{array}$ & $\begin{array}{l}3,96 \\
3,88\end{array}$ & $\begin{array}{l}0,422 \\
0,400\end{array}$ & 1,014 & 114 & 0,319 \\
\hline
\end{tabular}

Iz tablice 3 vidljivo je da se sudionici ne razlikuju značajno u učestalosti korištenja različitih vrsta učenja i poučavanja s obzirom na godine radnog staža, osim na subskali aktivnoga učenja uz primjenu suvremene informacijsko-komunikacijske tehnologije. Post hoc Tukeyev test je pokazao da sudionici s 21-25 godina staža znatno rjeđe koriste suvremenu informacijsko-tehnologiju od ispitanika koji imaju 6-10 godina radnog staža.

Tablica 3 Usporedba učestalosti primjene različitih oblika učenja i poučavanja s obzirom na godine radnog staža sudionika ( $\mathrm{N}=$ 116)

\begin{tabular}{|c|c|c|c|c|c|c|c|}
\hline Vrste poučavanja & $\begin{array}{c}\text { Trajanje } \\
\text { radnog staža } \\
\text { u godinama }\end{array}$ & N & M & SD & $\mathbf{F}$ & df & p \\
\hline \multirow{6}{*}{ Problemsko učenje } & $0-5$ & 14 & 3,55 & 0,339 & \multirow{6}{*}{0,210} & \multirow{6}{*}{5,110} & \multirow{6}{*}{0,958} \\
\hline & $6-10$ & 6 & 3,37 & 0,493 & & & \\
\hline & $11-15$ & 8 & 3,51 & 0,442 & & & \\
\hline & $16-20$ & 9 & 3,47 & 0,529 & & & \\
\hline & $21-25$ & 18 & 3,44 & 0,500 & & & \\
\hline & Više od 25 & 61 & 3,51 & 0,457 & & & \\
\hline \multirow{6}{*}{ Istraživačko učenje } & $0-5$ & 14 & 3,16 & 0,717 & \multirow{6}{*}{1,557} & \multirow{6}{*}{5,110} & \multirow{6}{*}{0,178} \\
\hline & $6-10$ & 6 & 3,43 & 0,413 & & & \\
\hline & $11-15$ & 8 & 3,09 & 0,714 & & & \\
\hline & $16-20$ & 9 & 2,83 & 0,441 & & & \\
\hline & $21-25$ & 18 & 2,54 & 0,654 & & & \\
\hline & Više od 25 & 61 & 2,88 & 0,584 & & & \\
\hline \multirow{6}{*}{ Suradničko učenje } & $0-5$ & 14 & 3,46 & 0,499 & \multirow{6}{*}{2,286} & \multirow{6}{*}{5,110} & \multirow{6}{*}{0,051} \\
\hline & $6-10$ & 6 & 3,68 & 0,147 & & & \\
\hline & $11-15$ & 8 & 3,85 & 0,444 & & & \\
\hline & $16-20$ & 9 & 3,91 & 0,385 & & & \\
\hline & $21-25$ & 18 & 3,48 & 0,571 & & & \\
\hline & Više od 25 & 61 & 3,77 & 0,722 & & & \\
\hline \multirow{6}{*}{$\begin{array}{c}\text { Aktivnosti usmjerene na razvoj } \\
\text { komunikacijskih kompetencija učenika i } \\
\text { njihove kompetencije učenja }\end{array}$} & $0-5$ & 14 & 3,55 & 0,278 & \multirow{6}{*}{0,369} & \multirow{6}{*}{5,110} & \multirow{6}{*}{0,869} \\
\hline & $6-10$ & 6 & 3,59 & 0,314 & & & \\
\hline & $11-15$ & 8 & 3,67 & 0,508 & & & \\
\hline & $16-20$ & 9 & 3,51 & 0,374 & & & \\
\hline & $21-25$ & 18 & 3,25 & 0,604 & & & \\
\hline & Više od 25 & 61 & 3,53 & 0,445 & & & \\
\hline \multirow{6}{*}{$\begin{array}{c}\text { Aktivno učenje uz primjenu suvremene } \\
\text { informacijsko-komunikacijske } \\
\text { tehnologije }\end{array}$} & $0-5$ & 14 & 3,16 & 0,717 & \multirow{6}{*}{2,886} & \multirow{6}{*}{5,110} & \multirow{6}{*}{0,017} \\
\hline & $6-10$ & 6 & 3,43 & 0,413 & & & \\
\hline & $11-15$ & 8 & 3,09 & 0,714 & & & \\
\hline & $16-20$ & 9 & 2,83 & 0,416 & & & \\
\hline & 21-25 & 18 & 2,54 & 0,654 & & & \\
\hline & Više od 25 & 61 & 2,88 & 0,584 & & & \\
\hline \multirow{6}{*}{ Direktno poučavanje } & $0-5$ & 14 & 3,88 & 0,360 & \multirow{6}{*}{0,369} & \multirow{6}{*}{5,110} & \multirow{6}{*}{0,869} \\
\hline & $6-10$ & 6 & 3,95 & 0,445 & & & \\
\hline & $11-15$ & 8 & 4,01 & 0,240 & & & \\
\hline & $16-20$ & 9 & 4,04 & 0,500 & & & \\
\hline & $21-25$ & 18 & 3,85 & 0,507 & & & \\
\hline & Više od 25 & 61 & 3,94 & 0,407 & & & \\
\hline
\end{tabular}


Sudionici koji su se stručno usavršavali u posljednjih 5 godina češće koriste problemsko i suradničko učenje u nastavi od onih koji se nisu usavršavali. Za ostale se strategije razlika nije pokazala značajnom (tablica 4).

Tablica 4 Usporedba učestalosti primjene različitih oblika učenja i poučavanja s obzirom na pohađanje stručnog usavršavanja sudionika $(\mathrm{N}=116)$

\begin{tabular}{|c|c|c|c|c|c|c|c|}
\hline Vrste poučavanja & $\begin{array}{l}\text { Stručno } \\
\text { usavršavanje }\end{array}$ & $\mathbf{N}$ & M & SD & t-test & df & $\mathbf{p}$ \\
\hline Problemsko učenje & $\begin{array}{l}\text { da } \\
\text { ne }\end{array}$ & $\begin{array}{l}88 \\
28\end{array}$ & $\begin{array}{l}3,56 \\
3,31\end{array}$ & $\begin{array}{l}0,426 \\
0,484\end{array}$ & 2,517 & 114 & 0,05 \\
\hline Istraživačko učenje & $\begin{array}{l}\text { da } \\
\text { ne }\end{array}$ & $\begin{array}{l}88 \\
28\end{array}$ & $\begin{array}{l}0,32 \\
0,30\end{array}$ & $\begin{array}{l}0,567 \\
0,464\end{array}$ & 1,894 & 114 & 0,061 \\
\hline Suradničko učenje & $\begin{array}{l}\text { da } \\
\text { ne }\end{array}$ & $\begin{array}{l}88 \\
28\end{array}$ & $\begin{array}{l}3,76 \\
3,52\end{array}$ & $\begin{array}{l}0,504 \\
0,386\end{array}$ & 2,331 & 114 & 0,05 \\
\hline $\begin{array}{l}\text { Aktivnosti usmjerene na razvoj komunikacijskih } \\
\text { kompetencija učenika i njihove kompetencije učenja }\end{array}$ & $\begin{array}{l}\text { da } \\
\text { ne }\end{array}$ & $\begin{array}{l}88 \\
28\end{array}$ & $\begin{array}{l}3,54 \\
3,36\end{array}$ & $\begin{array}{l}0,452 \\
0,451\end{array}$ & 1,882 & 114 & 0,062 \\
\hline $\begin{array}{l}\text { Aktivno učenje uz primjenu suvremene informacijsko- } \\
\text { komunikacijske tehnologije }\end{array}$ & $\begin{array}{l}\text { da } \\
\text { ne }\end{array}$ & $\begin{array}{l}88 \\
28\end{array}$ & $\begin{array}{l}2,87 \\
2,99\end{array}$ & $\begin{array}{l}0,643 \\
0,592\end{array}$ & $-0,912$ & 114 & 0,364 \\
\hline Direktno poučavanje & $\begin{array}{l}\text { da } \\
\text { ne }\end{array}$ & $\begin{array}{l}88 \\
28\end{array}$ & $\begin{array}{l}3,95 \\
3,89\end{array}$ & $\begin{array}{l}0,423 \\
0,386\end{array}$ & 0,664 & 114 & 0,508 \\
\hline
\end{tabular}

Potvrđeno je da na svim subskalama sudionici podjednako često primjenjuju navedene oblike učenja i poučavanja, odnosno razred u kojem sudionici rade ne utječe značajno na učestalost primjene određenih strategija učenja i poučavanja (tablica 5).

Tablica 5 Usporedba učestalosti primjene različitih oblika učenja i poučavanja s obzirom na razred u kojem sudionici rade ( $\mathrm{N}=$ 116)

\begin{tabular}{|c|c|c|c|c|c|c|c|}
\hline Vrste poučavanja & Razred & $\mathbf{N}$ & $M$ & SD & $\mathbf{F}$ & df & $\mathbf{p}$ \\
\hline \multirow{4}{*}{ Problemsko učenje } & prvi & 28 & 3,49 & 0,504 & \multirow{4}{*}{0,085} & \multirow{4}{*}{3,112} & \multirow{4}{*}{0,968} \\
\hline & drugi & 35 & 3,52 & 0,40 & & & \\
\hline & treći & 29 & 3,49 & 0,485 & & & \\
\hline & četvrti & 24 & 3,47 & 0,505 & & & \\
\hline \multirow{4}{*}{ Istraživačko učenje } & prvi & 28 & 3,15 & 0,679 & \multirow{4}{*}{0,324} & \multirow{4}{*}{3,112} & \multirow{4}{*}{0,808} \\
\hline & drugi & 35 & 3,10 & 0,437 & & & \\
\hline & treći & 29 & 3,23 & 0,577 & & & \\
\hline & četvrti & 24 & 3,10 & 0,524 & & & \\
\hline \multirow{4}{*}{ Suradničko učenje } & prvi & 28 & 3,62 & 0,531 & \multirow{4}{*}{2,290} & \multirow{4}{*}{3,112} & \multirow{4}{*}{0,082} \\
\hline & drugi & 35 & 3,60 & 0,440 & & & \\
\hline & treći & 29 & 3,89 & 0,517 & & & \\
\hline & četvrti & 24 & 3,73 & 0,424 & & & \\
\hline \multirow{4}{*}{$\begin{array}{l}\text { Aktivnosti usmjerene na razvoj komunikacijskih } \\
\text { kompetencija učenika i njihove kompetencije učenja }\end{array}$} & prvi & 28 & 3,48 & 0,474 & \multirow{4}{*}{1,705} & \multirow{4}{*}{3,112} & \multirow{4}{*}{0,170} \\
\hline & drugi & 35 & 3,40 & 0,398 & & & \\
\hline & treći & 29 & 3,65 & 0,043 & & & \\
\hline & četvrti & 24 & 3,48 & 0,509 & & & \\
\hline \multirow{4}{*}{$\begin{array}{l}\text { Aktivno učenje uz primjenu suvremene informacijsko- } \\
\text { komunikacijske tehnologije }\end{array}$} & prvi & 28 & 2,65 & 0,776 & \multirow{4}{*}{2,175} & \multirow{4}{*}{3,112} & \multirow{4}{*}{0,095} \\
\hline & drugi & 35 & 2,98 & 0,585 & & & \\
\hline & treći & 29 & 3,04 & 0,560 & & & \\
\hline & četvrti & 24 & 2,91 & 0,535 & & & \\
\hline \multirow{4}{*}{ Direktno poučavanje } & prvi & 28 & 3,87 & 0,416 & \multirow{4}{*}{0,674} & \multirow{4}{*}{3,112} & \multirow{4}{*}{0,570} \\
\hline & drugi & 35 & 3,92 & 0,439 & & & \\
\hline & treći & 29 & 4,02 & 0,381 & & & \\
\hline & četvrti & 24 & 3,91 & 0,421 & & & \\
\hline
\end{tabular}

U tablici 6 vidimo da zadovoljstvo poslom ne utječe ni na jednu subskalu, osim na subskalu aktivnosti usmjerene na razvoj komunikacijskih kompetencija učenika i njihove kompetencije učenja. Tukeyevim post hoc testom pokazalo se da učitelji koji su nezadovoljni poslom puno rjeđe koriste ovu strategiju poučavanja, u odnosu na učitelje koji su u potpunosti i djelomično zadovoljni poslom. 
Tablica 6 Usporedba učestalosti primjene različitih oblika učenja i poučavanja s obzirom na izraženo zadovoljstvo poslom (N= 116)

\begin{tabular}{|c|c|c|c|c|c|c|c|}
\hline Vrste poučavanja & $\begin{array}{l}\text { Zadovoljstvo } \\
\text { poslom }\end{array}$ & $\mathbf{N}$ & M & SD & $\mathbf{F}$ & df & p \\
\hline Problemsko učenje & $\begin{array}{l}\text { u potpunosti } \\
\text { zadovoljan } \\
\text { djelomično } \\
\text { zadovoljan } \\
\text { nezadovoljan }\end{array}$ & $\begin{array}{c}69 \\
43 \\
4\end{array}$ & $\begin{array}{l}3,53 \\
3,47 \\
3,25\end{array}$ & $\begin{array}{l}0,467 \\
0,426 \\
0,412\end{array}$ & 0,867 & 2,113 & 0,423 \\
\hline Istraživačko učenje & $\begin{array}{l}\text { u potpunosti } \\
\text { zadovoljan } \\
\text { djelomično } \\
\text { zadovoljan } \\
\text { nezadovoljan }\end{array}$ & $\begin{array}{c}69 \\
43 \\
4\end{array}$ & $\begin{array}{l}3,14 \\
3,15 \\
3,12\end{array}$ & $\begin{array}{l}0,592 \\
0,506 \\
0,320\end{array}$ & 0,003 & 2,113 & 0,997 \\
\hline Suradničko učenje & $\begin{array}{l}\text { u potpunosti } \\
\text { zadovoljan } \\
\text { djelomično } \\
\text { zadovoljan } \\
\text { nezadovoljan }\end{array}$ & $\begin{array}{c}69 \\
43 \\
4\end{array}$ & $\begin{array}{l}3,74 \\
3,69 \\
3,15\end{array}$ & $\begin{array}{l}0,489 \\
0,482 \\
, 0173\end{array}$ & 2,852 & 2,113 & 0,062 \\
\hline $\begin{array}{l}\text { Aktivnosti usmjerene na razvoj komunikacijskih } \\
\text { kompetencija učenika i njihove kompetencije učenja }\end{array}$ & $\begin{array}{l}\text { u potpunosti } \\
\text { zadovoljan } \\
\text { djelomično } \\
\text { zadovoljan } \\
\text { nezadovoljan }\end{array}$ & $\begin{array}{c}69 \\
43 \\
4\end{array}$ & $\begin{array}{l}3,55 \\
3,48 \\
2,92\end{array}$ & $\begin{array}{l}0,463 \\
0,420 \\
0,390\end{array}$ & 3,889 & 2,113 & 0,023 \\
\hline $\begin{array}{l}\text { Aktivno učenje uz primjenu suvremene informacijsko- } \\
\text { komunikacijske tehnologije }\end{array}$ & $\begin{array}{l}\text { u potpunosti } \\
\text { zadovoljan } \\
\text { djelomično } \\
\text { zadovoljan } \\
\text { nezadovoljan }\end{array}$ & $\begin{array}{c}69 \\
43 \\
4\end{array}$ & $\begin{array}{l}2,98 \\
2,82 \\
2,52\end{array}$ & $\begin{array}{l}0,599 \\
0,656 \\
0,814\end{array}$ & 2,614 & 2,113 & 0,204 \\
\hline Direktno poučavanje & $\begin{array}{l}\text { u potpunosti } \\
\text { zadovoljan } \\
\text { djelomično } \\
\text { zadovoljan } \\
\text { nezadovoljan }\end{array}$ & $\begin{array}{c}69 \\
43 \\
4\end{array}$ & $\begin{array}{l}3,98 \\
3,87 \\
3,63\end{array}$ & $\begin{array}{l}0,414 \\
0,408 \\
0,346\end{array}$ & 2,028 & 2,113 & 0,136 \\
\hline
\end{tabular}

Rezultati tablice 7 pokazuju da učitelji koji rade u školi koja se nalazi u gradu češće koriste strategije problemskog učenja, istraživačkog učenja, učenja uz primjenu suvremene informacijskokomunikacijske tehnologije od učitelja koji rade u školi koja se nalazi na selu. Za ostale se oblike učenja i poučavanja razlike nisu pokazale statistički značajne, odnosno i učitelji koji rade u gradu i oni koji rade na selu podjednako koriste direktno poučavanje, suradničko učenje te aktivnosti usmjerene na razvoj komunikacijskih kompetencija učenika i njihove kompetencije učenja.

Tablica 7 Usporedba učestalosti primjene različitih oblika učenja i poučavanja s obzirom na veličinu mjesta rada (N=116)

\begin{tabular}{|c|c|c|c|c|c|c|c|}
\hline Vrste poučavanja & $\begin{array}{c}\text { Veličina } \\
\text { mjesta } \\
\text { rada }\end{array}$ & $\mathbf{N}$ & M & SD & t-test & Df & $\mathbf{P}$ \\
\hline Problemsko učenje & $\begin{array}{l}\text { grad } \\
\text { selo }\end{array}$ & $\begin{array}{l}72 \\
44\end{array}$ & $\begin{array}{l}3,42 \\
3,62\end{array}$ & $\begin{array}{l}0,471 \\
0,390\end{array}$ & $-2,273$ & 114 & 0,025 \\
\hline Istraživačko učenje & $\begin{array}{l}\text { grad } \\
\text { selo }\end{array}$ & $\begin{array}{l}72 \\
44\end{array}$ & $\begin{array}{l}3,06 \\
3,28\end{array}$ & $\begin{array}{l}0,572 \\
0,493\end{array}$ & $-2,053$ & 114 & 0,042 \\
\hline Suradničko učenje & $\begin{array}{l}\text { grad } \\
\text { selo }\end{array}$ & $\begin{array}{l}72 \\
44\end{array}$ & $\begin{array}{l}3,70 \\
3,71\end{array}$ & $\begin{array}{l}0,522 \\
0,433\end{array}$ & $-0,132$ & 114 & 0,900 \\
\hline $\begin{array}{c}\text { Aktivnosti usmjerene na razvoj komunikacijskih } \\
\text { kompetencija učenika i njihove kompetencije učenja }\end{array}$ & $\begin{array}{l}\text { grad } \\
\text { selo }\end{array}$ & $\begin{array}{l}72 \\
44\end{array}$ & $\begin{array}{l}3,45 \\
3,57\end{array}$ & $\begin{array}{l}0,478 \\
0,414\end{array}$ & $-1,385$ & 114 & 0,169 \\
\hline $\begin{array}{l}\text { Aktivno učenje uz primjenu suvremene } \\
\text { informacijsko-komunikacijske tehnologije }\end{array}$ & $\begin{array}{l}\text { grad } \\
\text { selo }\end{array}$ & $\begin{array}{l}72 \\
44\end{array}$ & $\begin{array}{l}2,76 \\
3,12\end{array}$ & $\begin{array}{l}0,601 \\
0,620\end{array}$ & $-3,090$ & 114 & 0,003 \\
\hline Direktno poučavanje & $\begin{array}{l}\text { grad } \\
\text { selo }\end{array}$ & $\begin{array}{l}72 \\
44\end{array}$ & $\begin{array}{l}3,92 \\
3,95\end{array}$ & $\begin{array}{l}0,433 \\
0,386\end{array}$ & $-0,292$ & 114 & 0,771 \\
\hline
\end{tabular}

Studenti procjenjuju učestalost korištenja svih strategija aktivnoga učenja i poučavanja rjeđom nego što to procjenjuju učitelji. Također, studenti i učestalost direktnog poučavanja procjenjuju rjeđom od samih učitelja (tablica 8). 
Tablica 8 Usporedba razlike između učiteljskih tvrdnji i studentskih percepcija o korištenju aktivnih strategija učenja i poučavanja i direktnog poučavanja ( $\mathrm{N}=222)$

\begin{tabular}{|c|c|c|c|c|c|c|c|}
\hline Vrste poučavanja & $\begin{array}{c}\text { Uspoređivane } \\
\text { skupine }\end{array}$ & $\mathbf{N}$ & $\mathbf{M}$ & $\mathbf{S D}$ & $\mathbf{t}$-test & $\mathbf{D f}$ & $\mathbf{p}$ \\
\hline Problemsko učenje & $\begin{array}{c}\text { studenti } \\
\text { učitelji }\end{array}$ & $\begin{array}{c}106 \\
116\end{array}$ & $\begin{array}{c}2,74 \\
3,50\end{array}$ & $\begin{array}{c}0,745 \\
0,450\end{array}$ & $-9,069$ & 169,497 & $\mathrm{p}<0,001$ \\
\hline Istraživačko učenje & $\begin{array}{c}\text { studenti } \\
\text { učitelji }\end{array}$ & $\begin{array}{c}106 \\
116\end{array}$ & $\begin{array}{c}2,42 \\
3,14\end{array}$ & $\begin{array}{c}0,667 \\
0,551\end{array}$ & $-8,793$ & 220 & $\mathrm{p}<0,001$ \\
\hline $\begin{array}{c}\text { Suradničko učenje } \\
\text { učitelji }\end{array}$ & $\begin{array}{c}106 \\
116\end{array}$ & $\begin{array}{c}3,13 \\
3,70\end{array}$ & $\begin{array}{c}0,689 \\
0,488\end{array}$ & $-7,094$ & 187,460 & $\mathrm{p}<0,001$ \\
\hline $\begin{array}{c}\text { Aktivnosti usmjerene na razvoj } \\
\text { učenika i njihove kompetencije } \\
\text { učenja }\end{array}$ & $\begin{array}{c}\text { studenti } \\
\text { učitelji }\end{array}$ & $\begin{array}{c}106 \\
116\end{array}$ & $\begin{array}{c}2,69 \\
3,50\end{array}$ & $\begin{array}{c}0,648 \\
0,456\end{array}$ & $-10,664$ & 186,587 & $\mathrm{p}<0,001$ \\
\hline $\begin{array}{c}\text { Aktivno učenje uz primjenu } \\
\text { suvremene informacijsko- } \\
\text { komunikacijske tehnologije }\end{array}$ & $\begin{array}{c}\text { studenti } \\
\text { učitelji }\end{array}$ & $\begin{array}{c}106 \\
116\end{array}$ & $\begin{array}{c}2,57 \\
2,90\end{array}$ & $\begin{array}{c}0,739 \\
0,631\end{array}$ & $-3,610$ & 220 & $\mathrm{p}<0,001$ \\
\hline $\begin{array}{c}\text { Direktno poučavanje } \\
\text { učitelji }\end{array}$ & $\begin{array}{c}106 \\
\text { studenti }\end{array}$ & $\begin{array}{c}3,65 \\
3,91\end{array}$ & $\begin{array}{c}0,4450, \\
414\end{array}$ & $-4,921$ & 220 & $\mathrm{p}<0,001$ \\
\hline
\end{tabular}

\section{Odgovori na pitanje otvorenoga tipa}

Pitanje otvorenog tipa glasilo je: „Postoji li nešto što želite dodati, a nije obuhvaćeno ovim upitnikom?“. $\mathrm{Na}$ ovo je pitanje odgovorilo nekoliko učitelja i niti jedan student.

Odgovori su sljedeći:

Radim u drugome razredu s romskom nacionalnom manjinom. Oni ne govore hrvatski jezik ili ga vrlo slabo razumiju. O tehnologiji (računalo, Internet) nema govora jer žive u neljudskim uvjetima. Tek u predmetnoj nastavi kada donekle svladaju hrvatski jezik i mogu imati pristup školskom računalu, poneko dijete sigurno isto koristi za rad i učenje!

Stavke 81-90 ne mogu primijeniti jer u učionici nemam ispravnu tehničku podršku.

Fadam se da ću uskoro primjenjivati mogućnosti koje nude e-udžbenici. Nakon upitnika tražit ću da učenici više postavljaju pitanja o sadržajima koje su učili.

Uvjeti rada uvelike omogućuju ili onemogućuju rad i primjenu novih strategija.

- Učenici dolaze iz različitih imovinskih sredina i vrlo teško mogu primijeniti moderne (računalne) tehnike $u$ individualnom radu učenika kod kuće, zbog slabog imovinskog stanja učenika $i$ nejednakosti.

F Oprema (nast. pomagala) nije takva da bi učenici mogli samostalno raditi na računalu ili pretraživati Internet. Fond sati ne omogućava često korištenje aktivnih, suvremenih strategija. Učenici nemaju svoje računalo u razredu; gradivo je opširno, a sati malo.

\section{RASPRAVA}

Rezultati istraživanja prema samoprocjeni učitelja pokazuju da je učestalost primjene aktivnih oblika učenja i poučavanja povremena, a direktnog poučavanja česta što se vidi iz tablice 1 . Takvi rezultati upućuju na potrebu za češćom primjenom strategija aktivnoga učenja i poučavanja. Letina (2016) u svom istraživanju navodi slične rezultate što ukazuje da se stanje primjene aktivnih oblika učenja i poučavanja nije promijenilo ni dvije godine kasnije. Također je potvrđena statistički značajna razlika u primjeni spomenutih oblika učenja te su takvi rezultati u skladu s rezultatima Letine (2016). Dobiveno ukazuje da je nastava u našem školskom sustavu još uvijek pretežito usmjerena na učitelja, a ne na učenika, što bi zapravo trebao biti cilj nastave, jer samo takva nastava omogućuje cjeloviti razvoj učenika.

Rezultati pokazuju da od navedenih oblika aktivnoga učenja i poučavanja učitelji u nastavi Prirode i društva najčešće primjenjuju strategiju suradničkog učenja, a najrjeđe strategiju aktivnoga učenja i poučavanja uz primjenu suvremene informacijsko-komunikacijske tehnologije. Razlog ovakvog rezultata može biti i neodgovarajuća opremljenost učionica potrebnom tehnologijom, ali i nedovoljno 
razvijene kompetencije koje su potrebe za primjenu ove strategije. Na pitanje otvorenog tipa učitelji su često odgovarali da zbog loših uvjeta rada, ali i imovinskog stanja samih učenika ne mogu primjenjivati suvremenu informacijsko-komunikacijsku tehnologiju. Također, valja imati na umu da svaki rad u skupinama ili u paru nije uvijek suradničko učenje, jer među učenicima, unatoč tome što sjede zajedno, nedostaje upravo suradnja koja je temelj suradničkog učenja (Desforges, 2001; Klippert, 2001). Nadalje, pogledamo li tablicu 1., možemo uočiti da su rezultati dobiveni ovim istraživanjem u skladu s rezultatima Letine (2016). Prema dobivenim rezultatima postoji statistički značajna razlika u učestalosti primjene navedenih strategija učenja, pri čemu dominira primjena direktnog poučavanja. Mogući razlozi zašto učitelji češće ne primjenjuju strategije aktivnoga učenja i poučavanja, poput strategija istraživačkog i problemskog učenja, su zahtjevnija priprema i realizacije ovakve nastave (Borić i sur, 2010). Ono što je izuzetno zabrinjavajuće je još jedna potvrda dominacije direktnog poučavanja, koja je temelj tradicionalne nastave, a koja ne omogućuje razvoj učeničkih vještina, kritičkog mišljenja i pripremu učenika za život (Bognar i Matijević, 2002). Letina (2016) je u svom radu dobila slične rezultate uz iznimku što nije pronašla statistički značajnu razliku u učestalosti primjene aktivnosti usmjerenih na razvoj komunikacijskih kompetencija učenika i njihovih kompetencija učenja te problemske nastave.

lako je očekivano da postoje razlike u učestalosti primjene različitih oblika učenja i poučavanja u nastavi Prirode i društva između učitelja s obzirom na njihovu stručnu spremu, radni staž, sudjelovanje na stručnim skupovima, razred u kojem rade, izraženo zadovoljstvo poslom i sredinu u kojoj se nalazi škola u kojoj rade, rezultati nisu potvrdili sva ova očekivanja.

Nije utvrđena razlika u učestalosti primjene različitih oblika učenja i poučavanja s obzirom na stručnu spremu sudionika (tablica 2). U radu Letine (2016) možemo vidjeti da postoji značajna razlika za varijablu aktivnoga učenja uz primjenu suvremene informacijsko-komunikacijske tehnologije. Učitelji s visokom stručnom spremom češće su primjenjivali tu strategiju od učitelja s višom stručnom spremom. Razloge takvoj razlici možda možemo potražiti i u činjenici da su učitelji s višom stručnom spremom i oni s više radnog staža (zbog izmjene načina stjecanja stručne spreme za zvanje učitelj) što je tada s u skladu s rezultatima te iste razlike prema godinama radnog staža. Za ostale strategije učenja $i$ poučavanja nije dobila značajne razlike.

Što se tiče razlike u učestalosti primjene različitih oblika učenja i poučavanja s obzirom na godine radnog staža sudionika, ovo istraživanje djelomično potvrđuje očekivanje jer je pronađena značajna razlika u učestalosti korištenja strategije aktivnoga učenja i poučavanja uz primjenu suvremene informacijsko-komunikacijske tehnologije, što nam pokazuje tablica 3. Post hoc Tukeyev test je pokazao da sudionici s 21-25 godina radnog staža znatno rjeđe koriste suvremenu informacijskotehnologiju od ispitanika koji imaju 6-10 godina radnog staža. Takav se rezultat može pripisati tome što su mlađe generacije kompetentnije za korištenje suvremene tehnologije, jer su odrastale uz istu te su ju više primjenjivale. Ovi su rezultati u skladu s onima koje je dobila Letina (2016) u svom istraživanju. Ona je naime utvrdila da jedino na gore spomenutoj subskali postoji značajna razlika i to između sudionika koji imaju više od 25 godina radnog staža i onih koji imaju između 11-25 godina radnog staža.

Istraživanje djelomično potvrđuje našu pretpostavku vezanu uz učestalost primjene različitih oblika učenja i poučavanja u nastavi Prirode i društva s obzirom na to pohađaju li sudionici ili ne pohađaju stručne skupove. Učitelji koji su se stručno usavršavali u posljednjih 5 godina češće koriste problemsko i suradničko učenje u nastavi, za razliku od onih koji se nisu usavršavali. Za ostale se strategije razlika nije pokazala značajnom (tablica 4). Moguće je da se na stručnim skupovima, tj. na raznim oblicima 
stručnog usavršavanja više govori i uči o ovim strategijama učenja pa možda učitelji dobivaju više materijala i savjeta o tim strategijama te ih češće primjenjuju u nastavi. Stručno usavršavanje učitelja jedna je od najvažnijih pretpostavki kvalitetne, suvremene nastave, jer samo kompetentni učitelji, otvoreni za nove promjene mogu osuvremeniti današnju, još uvijek pretežito tradicionalnu nastavu. Najveći doprinos učenju učenika i njihovom napretku je učenje samih učitelja, a učitelj, kao i škola, mora biti u kontinuiranom razvoju i mijenjanju jer je on taj koji školu svojim radom mijenja (Stoll i Fink, 2000). Za razliku od ovih rezultata, Letina (2016) je u svom istraživanju dobila nalaz da se na svim strategijama učenja i poučavanja sudionici značajno razlikuju s obzirom na to jesu li ili nisu pohađali stručno usavršavanje u posljednjih pet godina. Učitelji koji su se usavršavali su češće koristili sve strategije, u usporedbi s onima koji se nisu usavršavali (to se odnosi čak i na direktno poučavanje).

Razlike u učestalosti primjene različitih oblika učenja i poučavanja s obzirom na razred u kojem sudionici rade (tablica 5) ovim istraživanjem nisu dokazane. Potvrđeno je da na svim subskalama sudionici podjednako često primjenjuju navedene oblike učenja i poučavanja, odnosno razred u kojem sudionici rade ne utječe značajno na učestalost primjene određenih strategija učenja i poučavanja. Letina (2016) je u svojem radu također dobila slične rezultate, osim na subskali aktivnoga učenja i poučavanja uz primjenu suvremene informacijsko-komunikacijske tehnologije, gdje se pokazalo da učitelji tu metodu više koriste u četvrtim razredima, nego u prvim.

Iz tablice 6. se vidi da zadovoljstvo poslom ne utječe ni na jednu subskalu, osim na subskalu aktivnosti usmjerenih na razvoj komunikacijskih kompetencija učenika i njihovih kompetencija učenja $(F=3,889$; $p<0,05)$ te je tako djelomično potvrđeno očekivanje vezano uz zadovoljstvo poslom. Učitelji koji su nezadovoljni poslom rjeđe koriste spomenutu strategiju učenja i poučavanja u odnosu na učitelje koji su djelomično ili potpuno zadovoljni poslom. Moguće je da učitelji koji su zadovoljni poslom ujedno imaju više volje i ulažu više truda u osmišljavanje aktivnosti poput debate, igranja uloga, projekata, zadavanja zadataka koji potiču više kognitivne procese, a od kojih se spomenuta strategija sastoji te je isto tako moguće da provođenje takvih aktivnosti povećava učiteljevo zadovoljstvo poslom. Rezultati Letine (2016) ne ukazuju na razlike niti na jednoj subskali.

Rezultati ovog istraživanja (tablica 7) pokazuju da učitelji koji rade u školi koja se nalazi u gradu češće koriste strategije problemskog učenja, istraživačkog učenja i strategije učenja uz primjenu suvremene informacijsko-komunikacijske tehnologije od učitelja koji rade u školi koja se nalazi na selu. Vjerojatno su škole u gradu opremljenije tehnologijom koja je potrebna za izvođenje aktivnih strategija učenja i poučavanja koje su se pokazale češće korištenima u školama koje se nalaze u gradu. Za ostale se oblike učenja i poučavanja razlike nisu pokazale statistički značajne.

Studenti procjenjuju učestalost korištenja svih strategija aktivnoga učenja i poučavanja rjeđom, nego što za sebe tvrde sami učitelji pa čak i direktnog poučavanja, što nam pokazuje tablica 8 . Škole uključene u ovo istraživanje birane su na način da su studenti, koji čine ispitanike ovog istraživanja, boravili u izabranim školama za vrijeme stručno-pedagoške prakse. Unatoč tome što oni nisu svakoga dana s učiteljima koji su sudjelovali u ovome istraživanju, rezultati su zabrinjavajući. Pozitivno je što su studenti primjenu direktnog poučavanja procijenili rjeđom, ali je ipak zabrinjavajuće nedostatno korištenje strategija aktivnoga učenja i poučavanja. Kako navodi Letina (2016), možda učitelji ni sami nisu svjesni razlike između pasivnog i aktivnog učenja, a uz to se i boje novih promjena. Na temelju odgovora učitelja na pitanje otvorenog tipa možemo zaključiti da je veliki problem našeg školskog sustava nedostatak nastavnih sredstava, preopširni plan i program te nedostatak vremena. Unatoč tome, promjene mogu krenuti samo od učitelja jer su oni temelj škole i temelj razvitka svakog djeteta. 
Od 106 studenata koji su sudjelovali u istraživanju, samo je njih 41,5\% (44 studenata) održalo nastavni sat iz predmeta Priroda i društvo, pri čemu su sami procijenili da nisu svi koristili strategije aktivnoga učenja i poučavanja. Ni jedan student četvrte godine nije održao nastavni sat iz predmeta Priroda $\mathrm{i}$ društvo, što je zapravo zabrinjavajuće. Kako bi budući učitelji bili kompetentni za izvođenje suvremene nastave, potrebno im je omogućiti da teorijsko znanje primjenjuju i u praksi. Slabe rezultate o spremnosti budućih učitelja za učinkovito i kvalitetno izvođenje suvremene nastave Prirode i društva, pokazalo je i istraživanje Letine (2013). Nikčević-Milković (2004) naglašava da je aktivno učenje rezultat aktivnog poučavanja pa to možemo povezati i sa studentima. Ako su studenti poučavani za korištenje aktivnih strategija te ako su i sami aktivno učili, tada će oni znati na takav način poučavati i svoje učenike.

\section{ZAKLUČAK}

Osvrnemo li se na nastavni predmet Priroda i društvo, na koji se osvrćemo u ovom radu, možemo vidjeti da je to zapravo jedan nastavni predmet koji učenici ne smiju upoznati samo sjedeći i čitajući udžbenike. Pročitamo li Nastavni plan i program (2006), Nacionalni okvirni kurikulum (2011) ili prijedlog Nacionalnog kurikuluma nastavnoga predmeta Priroda i društvo (2016), lako možemo uočiti da je stavljen naglasak na aktivno učenje i poučavanje.

Ovo istraživanje pokazalo je sljedeće:

potvrđuje se hipoteza kojom je pretpostavljeno da učitelji u nastavi Prirode i društva aktivne oblike učenja i poučavanja koriste povremeno (1x mjesečno), a direktno poučavanje često ( $1 \mathrm{x}$ tjedno);

potvrđena je hipoteza kojom se pretpostavlja da od navedenih oblika aktivnoga učenja i poučavanja učitelji u nastavi Prirode i društva najčešće primjenjuju strategiju suradničkog učenja, a najrjeđe strategiju aktivnoga učenja i poučavanja uz primjenu suvremene informacijsko-komunikacijske tehnologije;

potvrđena je hipoteza koja pretpostavlja da postoji statistički značajna razlika o učestalosti primjene određenih strategija učenja i poučavanja u nastavi Prirode i društva;

F odbačene su hipoteze koje se odnose na razlike u učestalosti primjene različitih oblika učenja i poučavanja s obzirom na stručnu spremu sudionika i na razred u kojem sudionici rade (ne postoji statistički značajna razlika ni za jednu subskalu strategija poučavanja);

djelomično su potvrđene hipoteze koje se odnose na godine radnog staža sudionika, pohađanje stručnih skupova, izraženo zadovoljstvo poslom i sredinu u kojoj se nalazi škola u kojoj sudionici rade;

potvrđuje se hipoteza kojom je pretpostavljeno da se procjene studenata o učestalost korištenja strategija aktivnoga učenja i poučavanja i direktnog poučavanja razlikuju od procjena samih učitelja.

Rezultati ovog istraživanja pokazali su da je primjena aktivnih strategija učenja i poučavanja povremena, što ukazuje na nužnost promjene u našem školskom sustavu. Cilj svakog učitelja trebao bi biti sretno i zadovoljno dijete, puno primjenjivog znanja i spremno za život koji ga čeka. Kako bi učitelji to postigli, važno je da se i sami kontinuirano, stručno usavršavaju. Razredna nastava, koja predstavlja početak učenja i susret s nekim novim svijetom koji je različit od onog na kojeg su djeca do sada bila navikla i koja će učenicima otvoriti nova vrata za novi svijet koji ih čeka, trebala bi biti usmjerena $k$ aktivnom učenju i poučavanju, jer samo ono učenicima omogućuje cjeloviti napredak kakav im je potreban i kakav zaslužuju. 


\section{METODIČKI ZNAČAJ}

Rezultati dobiveni ovim istraživanjem pokazali su da je naš školski sustav još uvijek pretežito tradicionalan i da je i sama nastava tako usmjerena. Unatoč brojnim istraživanjima koja su pokazala prednosti aktivnoga učenja i poučavanja, većih i značajnih promjena nema. Iz navedenoga proizlazi da su potrebne promjene u odgojno-obrazovnom procesu, usmjerene na osposobljavanje i usavršavanje učitelja za provedbu suvremene nastave u čijem je središtu učenik kao aktivni sudionik toga procesa.

\section{LITERATURA}

Balažinec, M. (2017). Primjena suvremenih nastavnih strategija u nastavi Prirode tijekom realizacije nastavne jedinice Sjemenka - klijanje. Educatio Biologiae, 3(1), 177-183.

Bognar, L., Matijević, M. (2002). Didaktika. Zagreb: Školska knjiga.

Boras, M. (2009). Suvremeni pristupi nastavi prirode i društva. Život i škola, 57(1), 40-49.

Calkin, J. i sur. (2003). Learning from Inquiry-Based Laboratories in Nonmayor Biology. Jornual od research in science teaching, 40(10), 986-1024.

De Zan, I. (2005). Metodika nastave prirode i društva. Zagreb: Školska knjiga.

Džaferagić-Franca, A., Omerović, M. (2012). Aktivno učenje u osnovnoj školi. Metodički obzori, 7(1), $167-181$.

Glasser, W. (1994). Kvalitetna škola. Zagreb: Educa.

Harle, W. (2001). Research in primary science education. Jornual of Biological Education, 35(2), 61-65.

HNOS - Nastavni plan i program za osnovnu školu (2006) na adresi

http://www.azoo.hr/images/AZOO/Ravnatelji/RM/Nastavni_plan_i_program_za_osnovnu_skolu__MZOS_2006_.pdf (20.2.2018.)

Kovačević, M. (2005). Aktivno učenje u interaktivnom odnosu sa sadržajima iz prirodoslovno-matematičkog područja. Život i škola, 13(1), 7-15.

Letina, A. (2013). Kompetencije učitelja primarnoga obrazovanja za djelotvornu organizaciju i izvođenje nastave prirode i društva. Život i škola, 59(1), 341-356.

Letina, A. (2016). Strategije aktivnog učenja u nastavi Prirode i društva. Školski vjesnik, 65(1), 7-31.

Matijević, M., Radovanović, D. (2011). Nastava usmjerena na učenika. Zagreb: Školske novine.

Nacionalni kurikulum nastavnoga predmeta Priroda i društvo - prijedlog (2016) na adresi http://mzos.hr/datoteke/7Predmetni_kurikulum-Priroda_i_drustvo.pdf (20.2.2018.)

Nacionalni okvirni kurikulum za predškolski odgoj i obrazovanje te opće obvezno i srednjoškolsko obrazovanje (2011) na adresi http://www.azoo.hr/images/AZOO/Ravnatelji/RM/Nacionalni_okvirni_kurikulum_-_listopad_2011_.pdf (20.2.2018.)

Nikčević-Milković, A. (2004). Aktivno učenje na visokoškolskoj razini. Život i škola, 50(2), 47-54.

Schallies, M. i Lembens, A. (2002). Student learning by research. Jornual of Biological Education, 37(1), 13-17.

Seifert i sur. (2009) An Invenstige, Cooperative Learning Approach to the General Microbiology Laboratory. CBE-Life Sciences Education, 8(2), 147-153.

Stevanović, M. (2004). Škola po mjeri učenika. Varaždinske Toplice: Tonimir.

Stoll, i., Fink, D. (2000). Mijenjajmo naše škole: kako unaprijediti djelotvornost u kvalitetu škole. Zagreb: Educa.

Topolovčan, T., Rajić, V. i Matijević, M., (2017). Konstruktivistička nastava: Teorija i empirijska istraživanja. Zagreb: Učiteljski fakultet Sveučilišta u Zagrebu. 